Article

\title{
Study of Groundwater Flow Properties in a Karst System by Coupled Analysis of Diverse Environmental Tracers and Discharge Dynamics
}

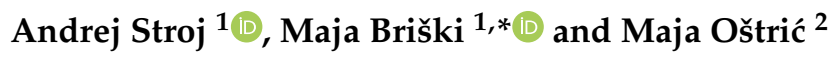 \\ 1 Department of Hydrogeology and Engineering Geology, Croatian Geological Survey,10000 Zagreb, Croatia; \\ astroj@hgi-cgs.hr \\ 2 Vodnogospodarski Odjel za Slivove Sjevernog Jadrana, Služba Korištenja voda, Hrvatske vode, 51000 Rijeka, \\ Croatia; maja.ostric@voda.hr \\ * Correspondence: mbriski@hgi-cgs.hr; Tel.: +385-921060597
}

Received: 21 July 2020; Accepted: 27 August 2020; Published: 31 August 2020

\begin{abstract}
Monitoring of various naturally present substances or physical properties of the water, commonly called environmental tracers, can provide valuable insight in characteristics of groundwater flow systems and intrinsic processes. Analysis of individual tracer data most often gives an ambiguous interpretation, but employment of multiple diverse tracers can greatly increase interpretation reliability. We monitored multiple natural tracers including spring water electrical conductivity, temperature, loads of major anions and cations, stable isotopes of water, and total organic carbon together with discharge dynamics on Krbavica springs located in the Croatian part of Dinaric Karst region. We also monitored dissolved oxygen concentration as an indicator of "excess air" dynamics in the spring water, which is a very rarely recognized and not properly understood phenomenon in the karst groundwater studies. Analysis of the monitoring data revealed main characteristics of the karst system, among which following can be emphasized: (1) oxygen concentration together with conductivity and temperature (parameters monitored with high temporal resolution) were strongly related to discharge dynamics, while seasonal patterns were absent; (2) supersaturation with oxygen confirmed presence of "excess air", most pronounced in high water conditions following the hydrograph peaks, indicating prevalence of closed flow conditions within the system; (3) electrical conductivity showed "anomalous" gradual decrease during the hydrograph recessions, attributed both to $\mathrm{CO}_{2}$ dynamics and mobilization of water from tiny fissures during high recharge conditions; and (4) stable isotope measurements confirmed good mixing of water within the system with mean residence time of a few years. Simultaneous monitoring of diverse tracer dynamics enabled detailed characterization of the karst system without excessive ambiguity.
\end{abstract}

Keywords: karst hydrogeology; environmental tracer; time series analyses; excess air; dissolved oxygen; Krbavica spring

\section{Introduction}

Karst aquifers are generally recognized as the most heterogeneous and complex groundwater flow systems e.g., [1,2]. A whole range of hydrogeological mediums from karst conduits and corrosion-widened fractures to tiny fissures and intergranular porosity within the karst aquifers cause simultaneous presence of contrasting groundwater flows. Due to the contrasting flow dynamics, different mediums rarely equilibrate and their interaction further influences flow properties [3]. Conduit network typically occupies a tiny percent of a total aquifer volume [4], but critically influences flow directions and velocities on a catchment scale. Low permeability fissures and intergranular 
porosity determine system storage and flow regulation capacity. Surficial, most intensely karstified subsurface zone called epikarst, together with soil cover has major control on water infiltration, storage and mixing [5,6]. Even if soil cover on the surface is absent or very thin, soil is still present within corrosion-widened fractures of epikarst. Water infiltrated in soil and epikarst zone partly escapes back to atmosphere due to plant transpiration [7]. Surface temperature and seasonal vegetation cycles control potential evapotranspiration intensity that consequently intensify seasonality of a spring discharges.

A detailed understanding of the functioning of all karst aquifer components, from soil and epikarst to conduit networks and fissured rock masses in vadose and phreatic zones, is crucial for successful protection and management of karst water resources. Impossibility of direct insight in their properties, especially on a catchment scale, presents a major problem for characterization of karst aquifers. Environmental tracers in groundwater are naturally present substances and physical properties of the water that are dependent on flow properties and processes happening within the groundwater flow system [8]. Their dynamics in a karst spring water (chemographs) in relation to discharge dynamics (hydrograph) are the reflection of all processes happening within the system. Therefore, analysis of a spring hydrograph and chemographs is a widespread approach to study karst system properties. However, particular tracer dynamics as well as discharge dynamics is typically dependent on a several different processes. Consequently, interpretation of a particular chemograph or hydrograph solely usually provides ambivalent conclusions, as various processes and settings can cause similar results. Employment of multiple diverse tracers in monitoring and analysis largely increases the level of detail and reliability of interpretation. Very fast dynamics of the karst system requires high temporal resolution of monitoring in order to reveal its characteristics in detail, so combined use of automated logging devices and sampling for parameters that cannot be measured continuously on the field usually provides the most detailed insight into the system properties.

Karst areas occupy approximately $50 \%$ of Croatia, mostly within the broader Dinaric Karst region. Water from karst aquifers presents a major drinking resource for the Croatian coastal area, where tourism is most concentrated, especially during summer season. Therefore, water supply needs during summer season in some areas are close, or even higher than natural capacities of available resources. As karst aquifers are typically very vulnerable to pollution due to possibility of very fast contaminant transport through the system, water protection in Croatian karst areas presents very important issue. However, effective protection is generally possible only if karst flow characteristics are determined in detail, both regarding spatial and temporal variations. The main goal of this study was detailed characterization of a groundwater flow properties in a karst system drained by Krbavica springs, situated in Croatian part of Dinaric Karst, as a basis for its effective protection. We achieved this by monitoring diverse environmental tracers together with the springs discharge dynamics, and additionally with hydrogeological mapping and artificial tracer testing, which are beyond the scope of this paper.

During most of the year in the main Krbavica spring bubbling is present. In addition, the spring water is known among local population to be occasionally lethal for fish, although it is a permanent spring with considerable discharge even in draught periods. Water supersaturation with air, or "excess air" [9], can cause fatal "gas bubble disease" in fish [10,11]. Therefore, the fish farming community is well aware of this phenomenon, although mechanisms that cause it are not the subject of their study. Presence of excess air in groundwater (mostly in alluvial aquifers) was also recognized by a number of hydrogeological studies that use noble or anthropogenic trace gases as indicators of groundwater residence time, origin, or recharge temperature [12-14]. These studies typically indirectly determined excess air by excessive concentration of the trace gases, but did not consider mechanisms responsible for its formation in detail. Generally, they attributed excess air to trapping and dissolution of air bubbles in soil or aquifer pores during recharge or water table fluctuations [13,14]. On the other hand, monitoring of air saturation dynamics in the spring water was very rarely conducted, although supersaturation with air is a phenomenon that periodically or permanently occurs in some karstic springs $[9,15]$. Air saturation directly controls dissolved oxygen concentration in the water and can 
be relatively easily monitored by automated logging devices. Therefore, we also included dissolved oxygen monitoring in high temporal resolution on the main Krbavica spring as an indicator of excess air dynamics. According to our knowledge, this was the first detailed study of excess air dynamics in a karst spring of Dinaric Karst region, as well as one of the few studies of this phenomenon worldwide.

\section{General Characteristics of the study Area}

The Krbavica springs are located at the edge of a karst polje called Krbavica polje (Figure 1). Krbavica polje is situated in the western part of Croatia, which belongs to a broader Dinaric Karst region. Dinaric Karst region spreads south from eastern Alps over a several countries of Southeast (SE) Europe, from Slovenia on Northwest (NW), across Croatia, Bosnia and Hercegovina, Montenergro to Albania on SE. The region is elongated in NW-SE direction, parallel to the eastern coast of Adriatic Sea (Figure 1). Dinaric Karst comprises the western part of the Dinaric mountain range, together with eastern Adriatic coast and islands. The area is composed predominantly of karstified carbonate rocks of Mesozoic and Tertiary age. Non-karstic rocks within the region occupy only relatively small and sporadically distributed areas, surrounded by karst terrains. Therefore, Dinaric Karst represents extensive and continuous karst area where boundaries between hydrogeological basins are mostly situated within deeply karstified terrains. Partial overlapping of the neighboring catchments is a common phenomenon proved by results of numerous artificial tracer tests. Due to the overlapping of catchments, several distant springs can share extensive recharge areas. Consequently, it is often not possible to define linear catchment boundaries, but they should be rather regarded as zonal and variable depending on hydrological conditions [16-19]. In such terrains artificial tracer tests presents a major tool for catchment delineation, but due to their general scarcity in comparison to the extent of the area, position of catchment boundaries are often approximate and uncertain.

There are two springs of Krbavica: the main spring, which is pumped for a public water supply of surrounding rural areas, and the periodic spring located approximately $400 \mathrm{~m}$ away from the main spring. Both springs are situated beneath the slopes of the bordering hills at approx. 700 meters above sea level ( $m$ a.s.l.), the periodic spring is situated a few meters above the main spring, while the highest hilltops in the hinterland reach approx. $1200 \mathrm{~m}$ a.s.l. Both springs historically had shapes of little lakes with upwelling of groundwater through the bottom sediments (Figure 2). Building of stone dams for the water mills formed spring lakes in the past. More recently, water intake building was built on the main spring and the spring pool was roofed (Figure 2). The main spring is flowing throughout the year, with minimal capacity after severe draught periods of a few tens of $\mathrm{L} / \mathrm{s}$. The periodic spring normally dries out every year during dry season (summer-autumn). The springs share the same karstic catchment situated in the hilly area of the hinterland. During the dry season the main spring drains the entire catchment area, while during the wet season the periodic spring also drains part of the catchment. Mean capacities of the main and the periodic spring are approximately 300 and $100 \mathrm{~L} / \mathrm{s}$, respectively, while maximums are slightly over $1000 \mathrm{~L} / \mathrm{s}$ on the main spring and up to $1000 \mathrm{~L} / \mathrm{s}$ on the periodic spring. Beside the described springs, there are no other significant springs in the Krbavica polje and its hinterland.

Catchment of the Krbavica springs is built entirely of karstified carbonate rocks of Mesozoic (Jurassic and Cretaceous) age (Figure 1). The western part of the catchment is predominantly built of limestones, while dolomite rock share gradually increases to the east. Dolomites are late diagenetic, and form bodies which alternate irregularly with limestones and dolomitic limestones. Main structural pattern of the area is formed by the system of first order faults oriented SE-NW to East-West, characterized by dextral horizontal and reverse displacements toward Southwest. The structural pattern is also affected by the numerous diagonal and transverse second order faults that interconnect former ones. Bedding is well expressed in most of the present rocks, and together with various faults and joints forms network of discontinuities that predispose karstification processes. Bedding in the hinterland of the springs is generally moderately inclined toward South and SE. 


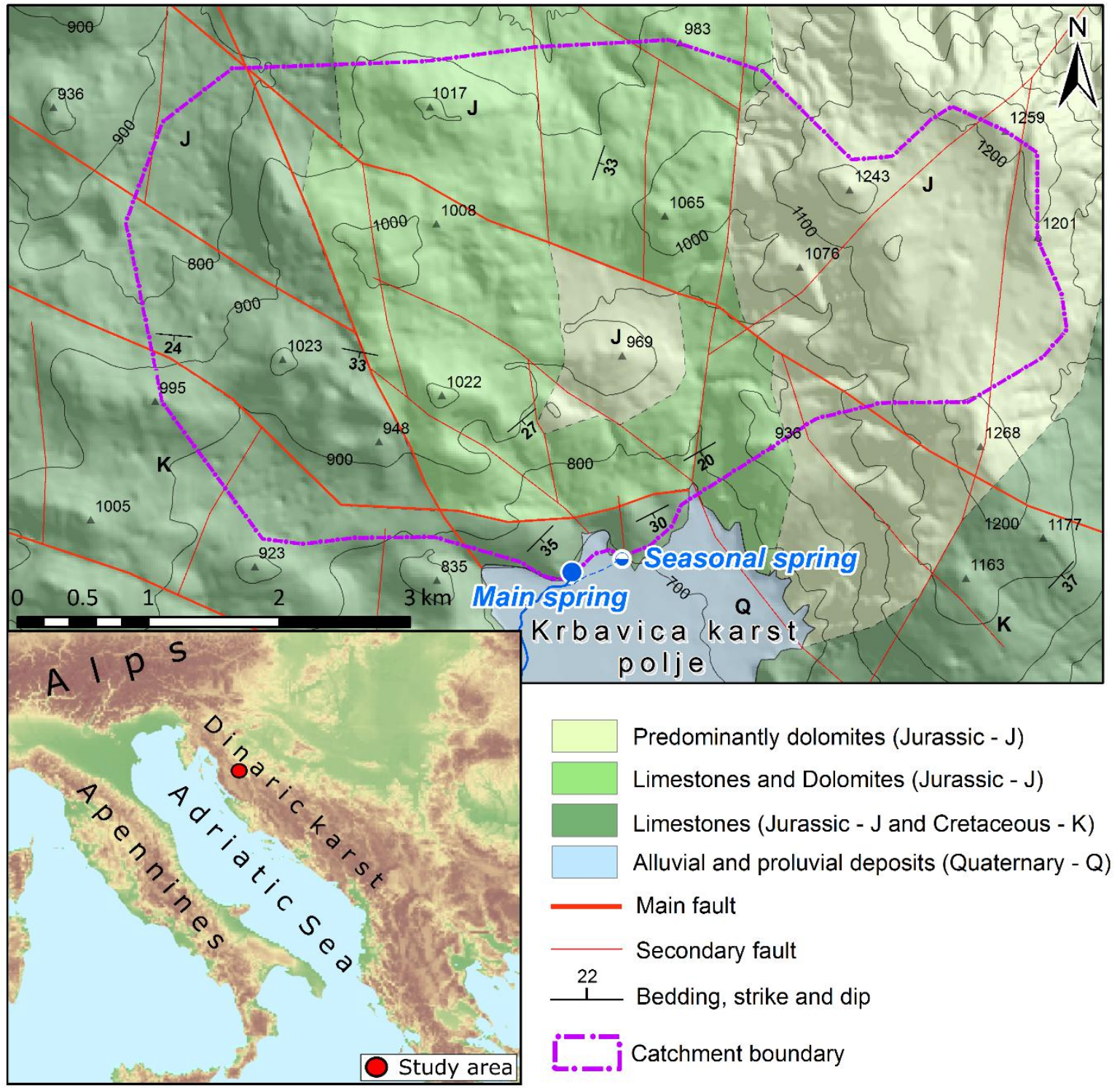

Figure 1. Position of the study area within the eastern Mediterranean region and hydrogeological map of the study area.

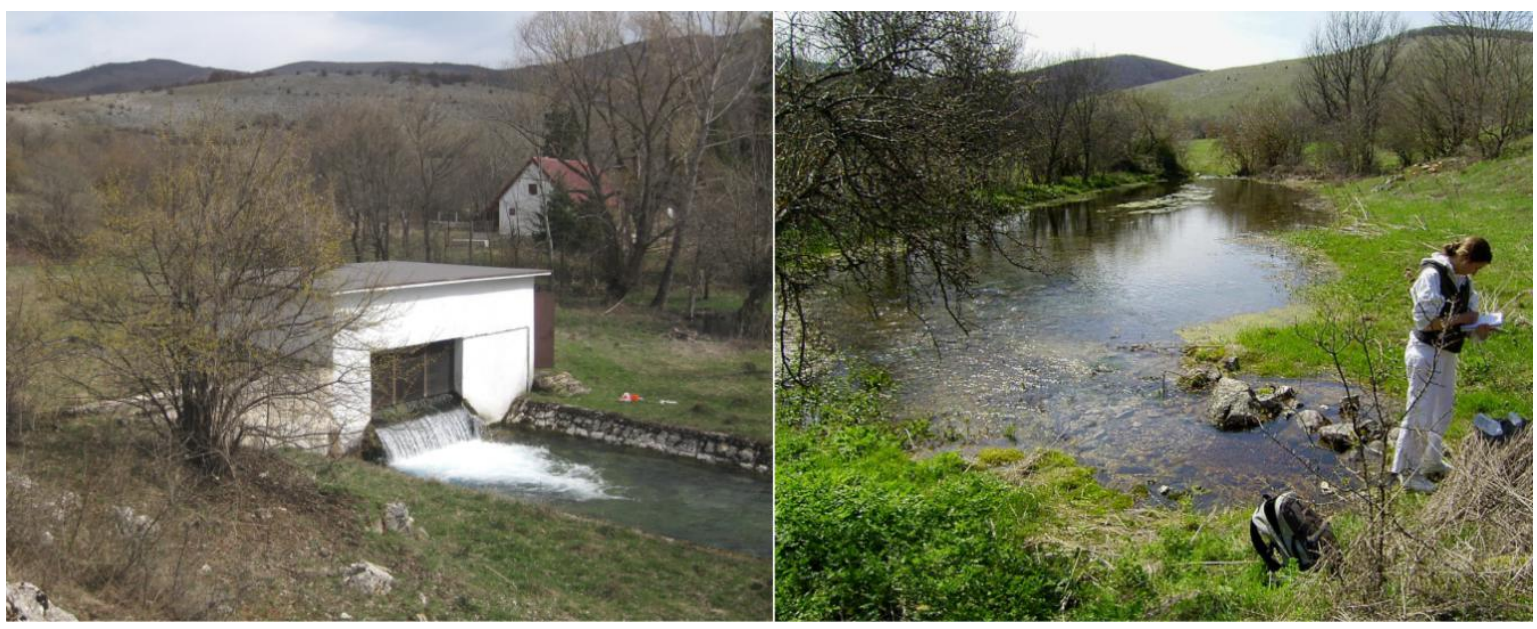

Figure 2. Intake building of the main spring (left) and periodic spring-lake (right). 
The area is characterized by transitional temperate to mountainous climate, with annual rainfall of approximately $1500 \mathrm{~mm}$, and annual average air temperature of approx. $6^{\circ} \mathrm{C}$ [20]. On average, greater share of precipitation falls during the colder part of the year, while yearly minimum is during summer months. In the entire catchment surficial water courses are absent, except a few torrential and rarely active gullies. The gullies are mostly formed on the prevailingly dolomitic terrains. Distinct karstic morphological features, i.e., dolines and karrenfields are mostly present on the limestone terrains in the western parts of the catchment, while terrains with significant share of dolomites have more "mellow" topography and bedrock mostly covered by thin, but continuous soil cover. There are no known caves within the catchment area. The area is mostly covered with forests, and to a lesser extent grasslands. There are neither settlements nor agriculture areas within the catchment, except for scarce sheep grazing. The only important human activity in the area is woodcutting.

None of the few artificial tracer tests performed in the vicinity showed groundwater connection with the Krbavica springs. Therefore, catchment area boundaries (Figure 1) were estimated based on: (1) tracing tests which revealed connections to the neighboring springs; (2) hydrological balance based on the springs discharge capacity and local precipitation; (3) lithological and structural characteristics; (4) elevation of the Krbavica springs and the morphology of the surrounding terrains; and (5) position and capacity of the neighboring springs. However, such estimated catchment area should be regarded approximate and uncertain in its distal parts.

\section{Materials and Methods}

Monitoring of the Krbavica springs (Figures 1 and 2) was initiated in September 2017 and lasted until May 2018. This 9-month monitoring period covered the ending part of the dry season as well as the wet season of winter and spring. The monitoring of the karst system consisted of hydrological monitoring of the springs and the monitoring of the physio-chemical properties of the springs water as well as the monitoring of precipitation (its quantity as well as its isotopic composition).

Spring discharge monitoring enabled analysis of the spring hydrograph, which is a basic parameter in determining the hydrodynamic characteristics of a karst system [21], while monitoring of additional water physio-chemical properties, i.e., environmental tracers greatly enhanced insight into groundwater flow processes [22,23].

Automatic measuring devices with internal memory (data loggers) were used to obtain continuous data of the springs dynamics in high temporal resolution (hourly interval). HOBO Water Level Data Loggers (Onset Computer Corporation, Bourne, MA, USA) were used to measure the water level of the two springs (the main and the periodic one). Specified accuracy of the loggers is $\pm 1 \mathrm{~cm}$ pressure of $\mathrm{H}_{2} \mathrm{O}$. The water level measurement data were subsequently compensated with respect to the atmospheric pressure changes, which were measured by a separate device of the same type. In order to determine the stage-discharge curve, i.e., the functional dependence of the discharge on changes in the water level, several flow measurements were performed under different hydrological conditions. The discharge of the two monitored springs was measured directly nine times (monthly intervals) using a digital water velocity meter (Global water flow probe, Global Water Instrumentation, College Station, TX, USA). Based on the experimentally determined stage-discharge curves, the continuous water level measurement data were transformed into continuous discharge data for both monitored springs.

For measuring of electrical conductivity (EC) and temperature of the main spring $\mathrm{HOBO}$ Fresh Water Conductivity Data Logger was used, with specified accuracy $\pm 0.1^{\circ} \mathrm{C}$ and $\pm 3 \%$ of EC readings. Specific electrical conductivity (SEC) on $25^{\circ} \mathrm{C}$ was calculated from measured EC and temperature data based on non-linear function according to the DIN EN 27,888 standard (Deutsches Institut für Normung-German Institute for Standardization). As SEC is directly related to total dissolved solid load of the water, its monitoring provided detailed insight in water mineralization dynamics.

The bubble formation that is visible in a spring pool of the main Krbavica spring indicated water supersaturation with gasses. Therefore, dissolved oxygen concentration, as an indicator of "excess air" 
in the spring water, was additionally monitored with $\mathrm{HOBO}$ Dissolved Oxygen Data Logger (accuracy of $0.5 \mathrm{mg} / \mathrm{L}$ ) with high temporal resolution (hourly record).

Precipitation monitoring was also achieved using an automatic logger (HOBO Rain Gauge RG-3 M) with an hourly measurement interval. The logger was placed in the vicinity of the main spring. As precipitations were the only source of recharge for the Krbavica karst system, precipitation monitoring in high temporal resolution defined input to the system in detail.

The springs discharge and precipitation dynamics were analyzed using descriptive statistics and time series analysis including autocorrelation (ACF) and cross-correlation functions (CCF) [24-27]. $\mathrm{ACF}$ and $\mathrm{CCF}$ served to characterize the average system memory, average response to precipitation and mutual dependence of the springs dynamics. Comparative analysis of dynamics of discharge and monitored physio-chemical parameters during individual storm events provided insight in interrelations between various processes happening within the system. Comparative analysis employed both analysis of detailed time series plots and hysteresis curves of particular physio-chemical parameters versus spring discharges.

Additionally, during the monitoring period spring water samples were collected monthly (eight times) from both springs, as well as bulk monthly precipitation samples from the location near the main spring. Precipitation samples were collected using an accumulation can with a layer of light pure paraffin oil that prevents sample evaporation. During collection of the samples, the spring water temperature, $\mathrm{pH}$ and electrical conductivity were measured using portable WTW probes (Xylem Analytics, Weilheim, Germany).

All sample analyses were performed in the hydrochemical laboratory of the Department of Hydrogeology and Engineering Geology of the Croatian Geological Survey. Spring water samples were analyzed for the main anions $\left(\mathrm{HCO}_{3}{ }^{-} ; \mathrm{Cl}^{-} ; \mathrm{SO}_{4}{ }^{2-}\right)$, cations $\left(\mathrm{Ca}^{2+} ; \mathrm{Mg}^{2+} ; \mathrm{Na}^{+} ; \mathrm{K}^{+}\right)$, Total Organic Carbon (TOC), and the composition of stable isotopes. Precipitation samples were analyzed for stable isotope composition solely. Alkalinity (as concentration of bicarbonate ion) was measured by volumetric titration using $1.6 \mathrm{~N} \mathrm{H}_{2} \mathrm{SO}_{4}$ to $\mathrm{pH}$ 4.5. The samples for the analysis of cations were acidified during sampling with $\mathrm{HNO}_{3}(65 \%)$. Principal dissolved cations $\left(\mathrm{Ca}^{2+} ; \mathrm{Mg}^{2+} ; \mathrm{Na}^{+} ; \mathrm{K}^{+}\right)$were measured by atomic absorption spectrophotometer (Aanalyst 700, PerkinElmer, Waltham, Massachusetts, USA). Analysis of principal anions $\left(\mathrm{Cl}^{-}\right.$and $\mathrm{SO}_{4}{ }^{2-}$ ) was performed using Spektrofotometer (model DL/2010, $\mathrm{HACH}$, Loveland, CO, USA). Total organic carbon (TOC) was analyzed using the QBD1200 Laboratory TOC Analyzer $(\mathrm{HACH})$. Stable isotopes of oxygen and hydrogen were analyzed using the Picarro L2130-i Isotope and Gas Concentration Analyzer (Picarro, Santa Clara, CA, USA), using the Secondary Water Isotopes Standard Kit (Picarro) for calibration of the results. All isotopic ratio results were reported as $\delta$-notation (\%o) relative to the Vienna Standard Mean Ocean Water (VSMOW) standard.

Results of the principal anion and cation analysis in monthly water samples provided definition of the spring water's hydrochemical facies by construction of a Piper diagram [28], which graphically presents principal ion ratios. Beside hydrochemical facies, major ion content of the spring water can also indicate relative residence time of the water in the subsurface. Water in contact with carbonate rocks approaches the saturation with respect to calcite much faster than with respect to dolomite, since dolomite dissolution kinetics is approximately two orders of magnitude slower than calcite $[1,29,30]$. Therefore, $\mathrm{Mg} / \mathrm{Ca}$ molar ratio can serve as an indicator of duration of water-rock interaction, i.e., groundwater residence time [31-34]. However, if distribution of limestones and dolomites within a catchment is not uniform, variations in the $\mathrm{Mg} / \mathrm{Ca}$ ratio can also be a consequence of different water origin and flow path, so attention is required in interpretation of $\mathrm{Mg} / \mathrm{Ca}$ ratio data.

Stable isotope analyses of oxygen and hydrogen in the spring water and precipitation samples served to define spring water origin by its comparison with local precipitation characteristics: spring water isotope values were plotted and compared with the local meteoric water line defined by local precipitation isotopic characteristics [35]. In order to take water flux in the system into account, 
precipitation values were weighted with amount of rainfall before comparison with spring water values. Mean precipitation values were weighted using the following equation:

$$
\delta_{\mathrm{w}}=\sum_{i=1}^{n} P_{i} \delta_{i} / \sum P_{i}
$$

where $\delta_{i}$ is weighted mean precipitation value (\%); $P_{i}$ and $\delta_{i}$ are the monthly precipitation amount $(\mathrm{mm})$ and the isotopic composition (\%o), respectively; and $\mathrm{n}$ is the number of months.

Isotopic analyses also enabled a rough estimation of spring water mean residence time (MRT) in the aquifer by using a simple equation based on observed annual oscillation amplitudes in precipitation and spring water samples:

$$
\mathrm{T}=\frac{1}{\omega} \sqrt{\left(\frac{A}{B}\right)^{2}-1}
$$

where $\mathrm{T}$ is the mean residence time; $A$ and $B$ are the amplitudes of the seasonal variation of the isotopic content in the aquifer recharge (precipitation) and the spring water, respectively; and $\omega$ is the angular frequency. A detailed description and a theoretical background of the applied equation are given in References [36,37].

\section{Results}

The monitoring of the springs started at the end of the dry season in September 2017 and ended at the end of the wet season in May 2018 (Figure 3). The monitoring period lasted over eight months. Both low water conditions at the end of extended recession period (spring-summer 2017) and high water conditions (winter-spring 2018) were covered. Therefore, complete range of the hydrological conditions was recorded although monitoring period lasted less than 1 year. On the main spring water was occasionally pumped with the capacity of $18 \mathrm{~L} / \mathrm{s}$, producing slight disturbances of its hydrograph.

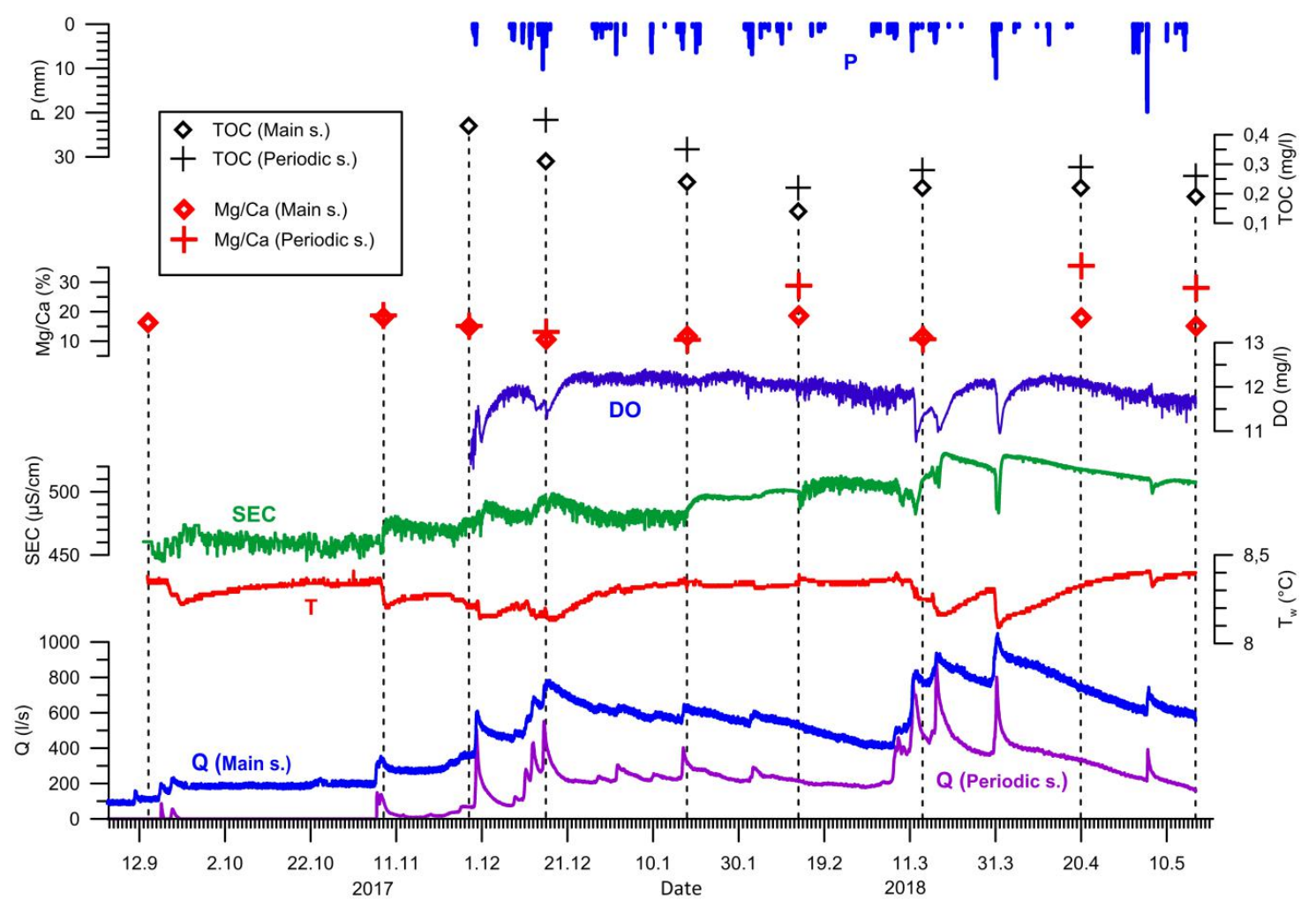

Figure 3. Discharge (Q), total organic carbon content (TOC), $\mathrm{Mg} / \mathrm{Ca}$ molar ratio, and precipitation (P) data for both Krbavica springs; temperature (T), specific electrical conductivity (SEC) and dissolved oxygen (DO) data monitored in the main spring. 


\subsection{Discharge Dynamics}

Monitoring of the springs discharge started in September 2017 at very low water conditions at the end of the recession period (after four months of below average precipitations, from May until August 2017, based on national meteorological monitoring stations data, Croatian Meteorological and Hydrological Service). The flow on the main spring was then $100 \mathrm{~L} / \mathrm{s}$, while the periodic spring was dry (Figure 3). Precipitations later in September were significantly above average with a few very intense rainfalls, but flood peaks on the both springs were moderate. The periodic spring quickly went dry again afterwards. First more significant hydrograph peaks occurred in November, after which the periodic spring remained active until the end of the monitoring period. Multiple intensive peaks occurred in December 2017, and again in March 2018 when maximum discharges were recorded. The highest recorded peak discharge on the main and the periodic springs reached $1050 \mathrm{~L} / \mathrm{s}$ and $800 \mathrm{~L} / \mathrm{s}$, respectively.

During medium-to-high water conditions, capacity of the periodic spring was approximatley $40 \%$ of the main spring, except in the peaks when it reached up to $80 \%$. This was a consequence of much more pronounced peaks on the periodic spring hydrograph. Besides the attenuated peaks on the main spring, dynamics of both springs were similar and synchronous. Similar dynamics were reflected by the similar autocorrelation functions (ACFs), computed for the period when both springs were active (November 2017 to May 2018, Figure 4). Autocorrelation coefficient dropped below 0.2 value, often defined as a system memory duration [24,25], after approximately 20 days for both springs. It should be noted that ACF depends on both the system properties and the frequency of the storm events. Therefore, system memory would have been probably longer if complete wet and dry season hydrograph had been taken for the perennial spring. Attenuated peaks of the main spring hydrograph were reflected by its linear ACF decrease. Cross-correlation function (CCF) of the main and periodic spring discharges shows highest coefficient (0.82) with no delay, what confirmed synchronicity of the springs dynamics (Figure 4). Average delays of the hydrograph peaks after the precipitation events were approximately $20-25 \mathrm{~h}$ on the main, and $12-17 \mathrm{~h}$ on the periodic spring (CCF based on hourly data). Attenuated peaks of the main spring hydrograph significantly lowered maximum CCF coefficient in comparison to the periodic spring.
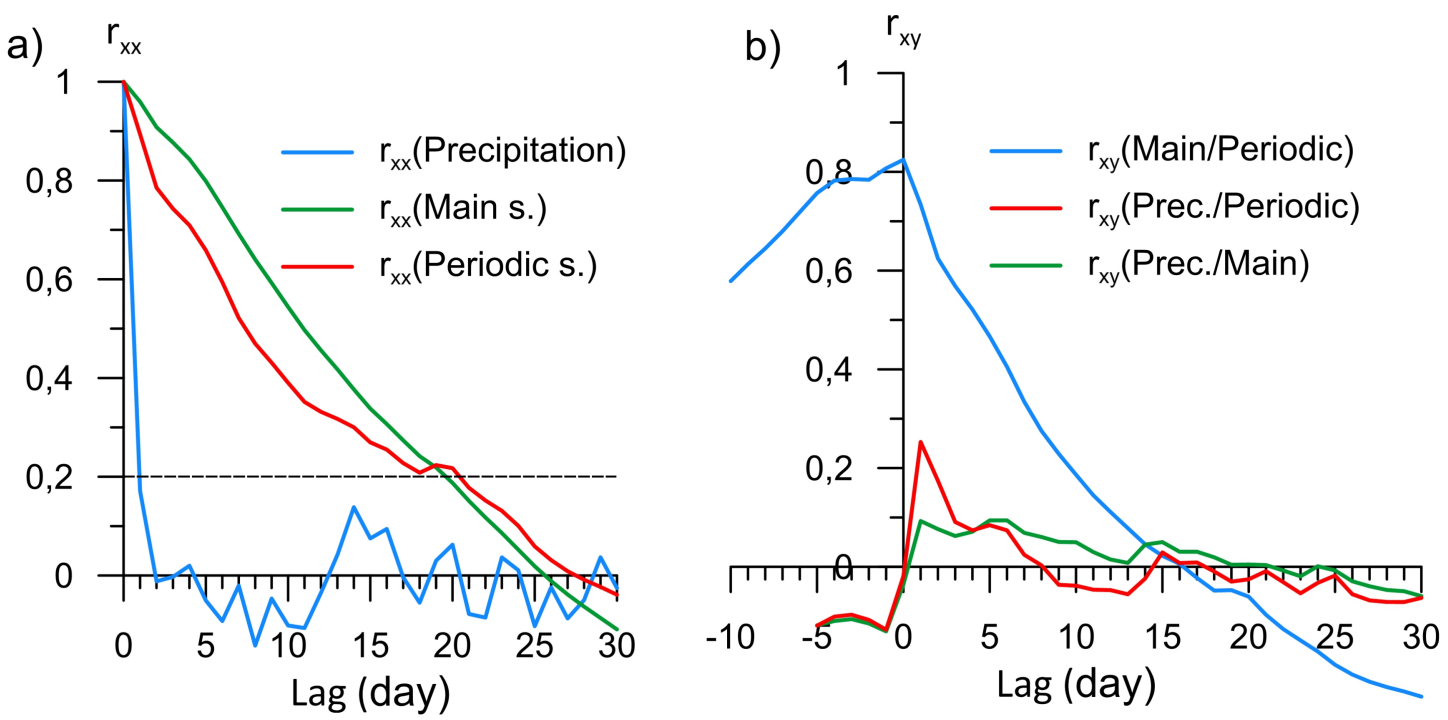

Figure 4. (a) Autocorrelation (ACF) and (b) Cross-correlation functions (CCF) of the measured precipitations, the main and the periodic spring discharges (based on average daily values; $r_{x x}-A C F$ coefficient; $r_{x y}-C C F$ coefficient of input/output series). 


\subsection{Major Ion Content}

The analysis of the chemical composition of the spring waters showed that the dominant anions were $\mathrm{Ca}^{2+}, \mathrm{Mg}^{2+}$, and $\mathrm{HCO}_{3}{ }^{-}$. All the results of the principal anion and cation analyses were plotted on a Piper diagram (Figure 5) to define spring water hydrochemical facies. All the water samples from monitored springs were the calcium-magnesium-bicarbonate water type. This confirmed absence of groundwater contact with non-carbonate rocks in the subsurface (e.g., evaporites which are present in the base of some Dinaric Karst poljes and plateaus, usually covered by unconsolidated sediments). Some of the periodic spring samples showed increased content of magnesium ions, which was due to the dominance of dolomitic rocks in its hinterland. All other ion contents were very stable. Spring water mineralization was in the range of 330-400 mg/L for the main spring, and 380-430 mg/L for the periodic spring (calculated from the chemical analysis of the major anions and cations).

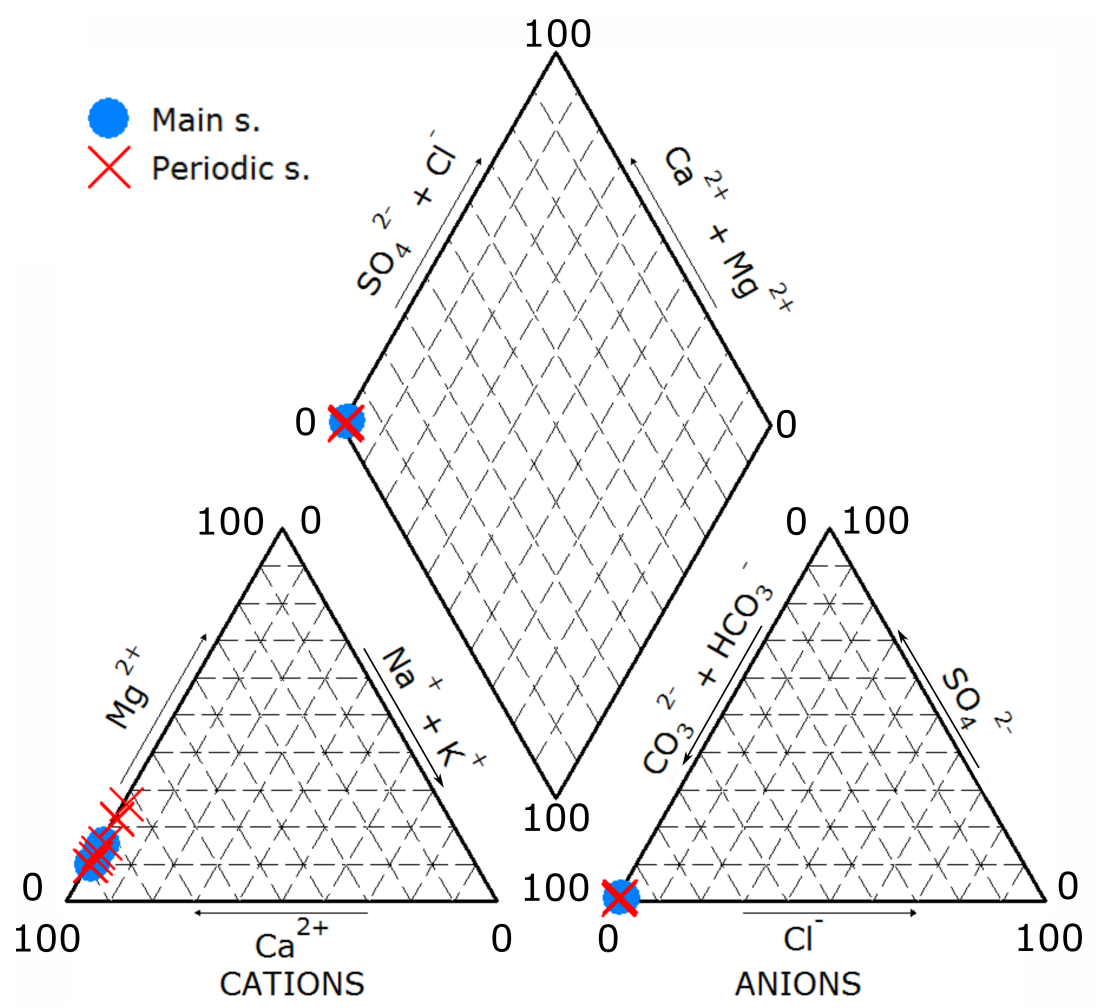

Figure 5. Piper diagram of the springs water.

$\mathrm{Mg} / \mathrm{Ca}$ ratio in collected water samples is shown on Figure 3 together with the hydrographs and other monitored parameters. It should be noted that in the hinterland of the periodic spring dolomite rocks are widespread, while main spring is located towards prevailingly limestone areas (Figure 1). During low water periods entire catchment is drained by the main spring, while in high water conditions catchment is partly drained also by the periodic spring. Due to varying amounts of dolomites within the catchment, variations in $\mathrm{Mg} / \mathrm{Ca}$ ratio of the periodic spring and the main spring have to be considered separately and interpreted both by groundwater residence time and as a result of variations in drainage directions and water origin. However, on the both springs $\mathrm{Mg} / \mathrm{Ca}$ ratio was lower during the hydrograph peaks, and higher in recession periods. Increases in $\mathrm{Mg} / \mathrm{Ca}$ ratio were significantly more pronounced on the periodic spring, which was probably related to the dominance of dolomitic rocks in its hinterland. Highest $\mathrm{Mg} / \mathrm{Ca}$ ratio on both springs occurred during relatively early stages of recessions, while slight decrease was observed in later stages (e.g., recession during April-May 2018, Figure 3). This implies that the highest share of "old" water, i.e., the longest mean residence time of spring water was during relatively early stages of recession periods. This can be attributed to mobilizing of water contained in tiny fractures by increased pressure during high recharge 
conditions, while in low recharge conditions that water is immobilized by adhesion forces. Correlation of $\mathrm{Mg} / \mathrm{Ca}$ ratio and SEC values was generally absent, indicating that these parameters were controlled by different processes. Nevertheless, more frequent sampling, especially during high water periods, is required to gain more detailed insight in $\mathrm{Mg} / \mathrm{Ca}$ dynamics.

\subsection{Specific Electrical Conductivity (SEC) Dynamics}

Correlation of SEC values (monitored on the main spring) with total dissolved solid (TDS) contents, calculated from the results of the major anions and cations chemical analysis, was strong (Figure 6a). This allowed to use SEC dynamics, monitored in high temporal resolution (hourly data), as a good indicator of a water mineralization dynamics.
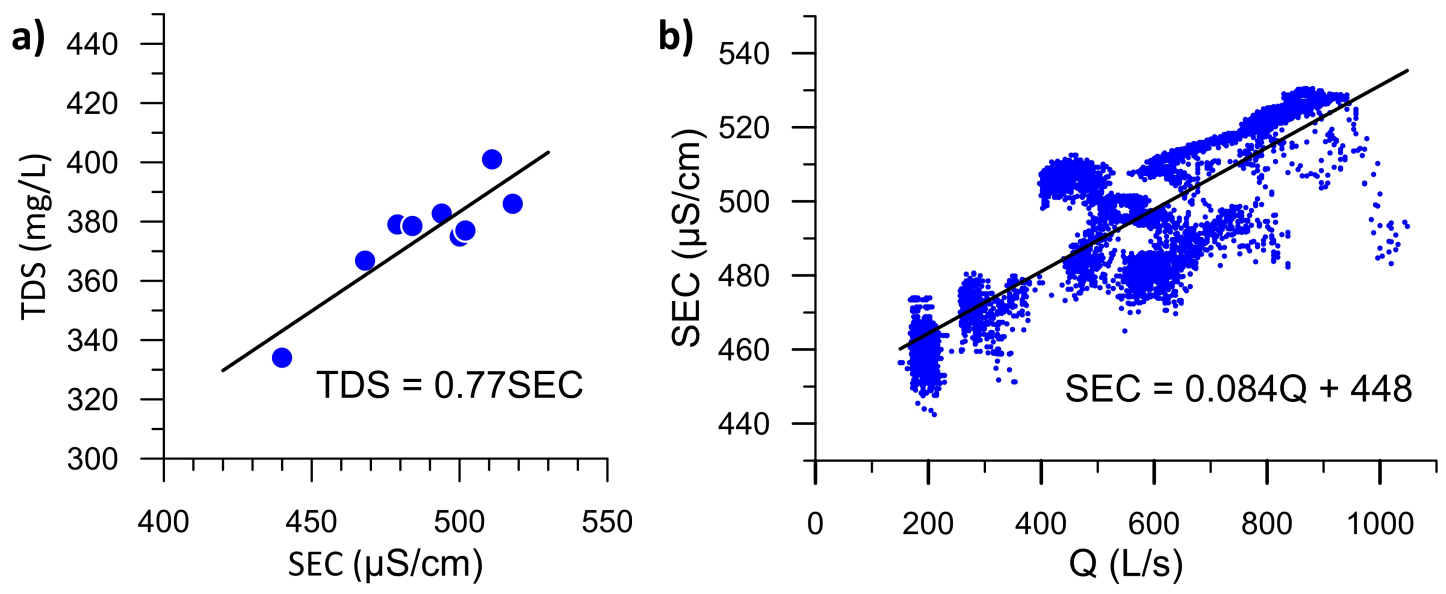

Figure 6. Correlation of specific electrical conductivity (SEC) measurements of the main spring water with (a) total dissolved solids (TDS) contents in water samples (based on analysis of major ions); and (b) simultaneous discharges of the main spring.

Moderate noise, occasionally present in SEC data (Figure 3), was produced by bubble formation on the logger sensor due to a water supersaturation with gasses. However, overall dynamics was well identifiable, especially during high water conditions when stronger flow across the sensor removed bubbles more efficiently. Monitoring revealed gradual decrease of SEC during the hydrograph recessions, while SEC rose significantly shortly after the peaks (Figure 3). Consequently, the highest values were recorded in high water conditions and the lowest at the end of dry season (September 2017). During the more intensive peaks of the hydrograph, SEC briefly decreased before subsequent increase. Fall intensities were proportional to the intensities of the hydrograph peaks. Generally, SEC was positively correlated with the spring discharge during the major part of the monitoring period, with exception of very short periods during the major hydrograph peaks (Figure $6 b$ ).

SEC monitoring showed that the most mineralized water appeared at the spring shortly after the flood peaks, i.e., in high water conditions, and afterwards mineralization started to decline gradually during the recession periods (Figures 3 and 7). Therefore, the spring water was least mineralized at the end of the longest recession period. This was contrary to usual observations of gradual increase of mineralization (or SEC) during hydrograph recession periods on karst springs (e.g., [23,34,38-40]). Similar SEC increases observed in high water conditions shortly after the flood peaks Author [17] called "anomalous", and explain it by a variable catchment boundaries and flow directions.

However, dissolved $\mathrm{CO}_{2}$ concentration in water and duration of a water-rock interaction are two principal factors that control carbonate dissolution $[29,41]$. Calcite dissolution kinetics is relatively fast at high to moderate under-saturation, enabling the groundwater to reach approximately $90 \%$ saturation within a few days [42,43], but afterward, dissolution slows down by a few orders of magnitude [44]. Groundwater with residence time below several days is usually present on karst springs only during and shortly after the intense hydrograph peaks [45-47]. Therefore, it can be 
concluded that mineralization of karst spring water is dominantly controlled by $\mathrm{CO}_{2}$ concentration during hydrograph recessions, while residence time can have major role during hydrograph peaks.

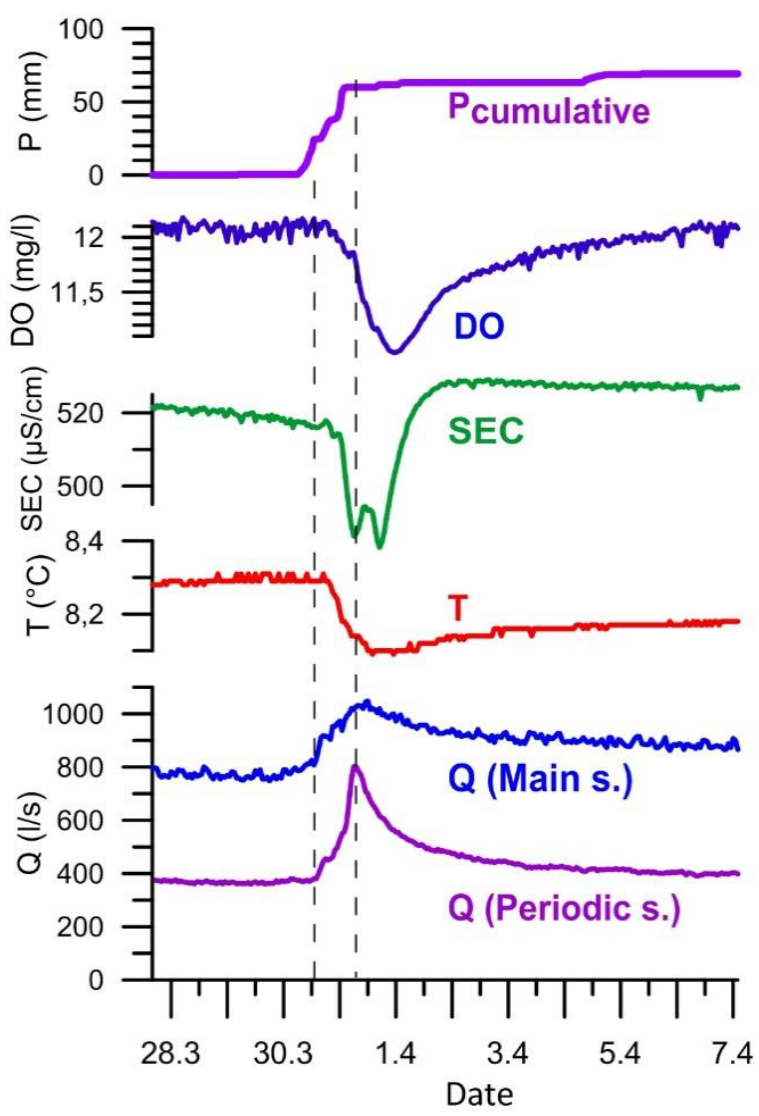

Figure 7. Detailed dynamics of the main spring temperature (T), specific conductivity (SEC) and dissolved oxygen (DO), the springs discharges $(\mathrm{Q})$ and cumulative precipitation $(\mathrm{P})$ during the maximum recorded flood event in March-April 2018.

Authors [31] attributed SEC increases shortly after the hydrograph peaks to soil/epikarst water transfer to the spring. Soil cover is generally recognized as the main source of $\mathrm{CO}_{2}$ in karst systems [48,49], and some studies report even higher $\mathrm{CO}_{2}$ concentrations measured within the vadose zone below [50,51]. Therefore, air originating from epikarst and/or vadose zone, dissolved in water, significantly increases $\mathrm{CO}_{2}$ concentration, and consequently solubility of carbonate rocks. Further, supersaturation with $\mathrm{CO}_{2}$ rich air can additionally increase $\mathrm{CO}_{2}$ concentration in water. Based on the presented, increased SEC, i.e., mineralization of the Krbavica spring water, can be attributed to increased $\mathrm{CO}_{2}$ concentrations during higher flow conditions due to water supersaturation with air from epikarst/vadose zone. Supersaturation with air was indirectly confirmed by monitoring of dissolved oxygen dynamics (described in detail in the following section), as well as observations of bubble formation in the spring pool. An additional mechanism that could influence SEC dynamics is mobilization of water contained in tiny fractures during high recharge conditions due to rising pressures. Such water has longest residence time within the system, and therefore sufficient time to reach equilibrium saturation. However, lack of strong correlation between SEC and $\mathrm{Mg} / \mathrm{Ca}$ ratios indicate that water residence time is not the only controlling factor for SEC dynamics.

Short-term decreases of SEC, which preceded increases, started with a delay of approx. 10-20 h (compared to the hydrograph), varying for the particular high water event. SEC drops showed double lows shape, observable when examined in detail (Figure 7). Drops of SEC marked an increase of freshly infiltrated water share that efficiently bypassed storage reservoirs in soil, epikarst, and vadose zone, and due to fast transport through conduit systems appeared at the spring significantly under-saturated 
in respect to calcite $[47,52]$. Double lows pointed to existence of the two main tributaries (conduit systems) to the spring with a different reaction time. During the highest recorded flood event first low was simultaneous with the hydrograph peak, while the second, slightly more intensive, had delay of approx. $10 \mathrm{~h}$ (Figure 7).

Hysteresis curve of SEC vs. discharge during the most intensive flood event (March-April 2018; Figure 8) shows SEC dynamics during the rapid discharge increase and following gradual decrease in detail. After the initial delay (approximately $8 \mathrm{~h}$ ), characterized by slight rising, SEC values started to drop and reach first minimum within a few hours, synchronous with the hydrograph peak (phase 1 on Figure 8). After a subsequent moderate rise, SEC drops again to the second minimum (phase 2), and afterwards starts to rise in negative linear relation with the spring discharge (phase 3) until reaching the maximum of the complete monitoring period $(530 \mu \mathrm{S} / \mathrm{cm})$. Approximately 2 days after the hydrograph peak, SEC started to follow positive linear relationship with the spring discharge, which characterized majority of the monitoring period (Figure 6b).
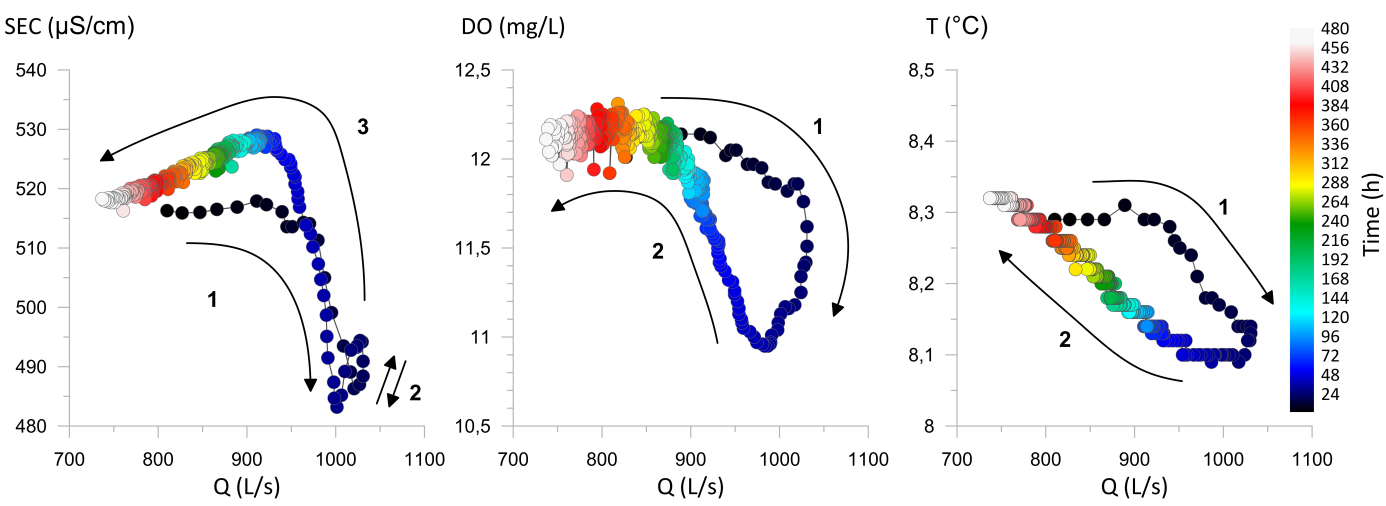

Figure 8. Hysteresis curves of specific conductivity (SEC), dissolved oxygen (DO), and temperature (T) vs. discharge (Q) during maximum recorded flood event in March-April 2018 (Figure 7). Numbers indicate succession of different phases in dynamics (note that phases are not synchronous and analogous among different parameters: SEC dynamics is separated into three, while DO and T into two phases).

\subsection{Temperature Dynamics}

Water temperature on the main spring was fluctuating within a narrow range of $8.1-8.4{ }^{\circ} \mathrm{C}$ during the complete monitoring period. Fluctuations were clearly related to discharge dynamics on flood event timescales, while there was no observable seasonal pattern. This reflected efficient temperature equilibration within the system during most of the monitoring period, except periods after the significant hydrograph peaks. Moderately steep drops after the increase of discharge (phase 1 on Figure 8) marked temperature dynamics at high recharge events, followed by slow recoveries to pre-event values (Figures 3 and 7, phase 2 on Figure 8).

Slower dynamics (especially much slower recovery) in comparison to SEC (recovery of several weeks compared to 1-2 days; Figures 7 and 8) reflected highly reactive nature of temperature as an environmental tracer [53]. Consequently, recorded temperature fluctuations did not directly mark arrival and subsequent decline of freshly infiltrated water flux, but rather cooling and subsequent rewarming of the rocks surrounding the conduits and most transmissive fractures. Inertia in temperature recovery after floods reflected slow temperature equilibrating of rocks surrounding conduits with the rest of the system. Faster cooling can be explained by much larger temperature difference between conduit walls and fast-infiltrated water during high recharge conditions in comparison to subsequent warming by slightly warmer water coming from less permeable, i.e., temperature unaffected volumes during recession. 


\subsection{Total Organic Carbon (TOC)}

Total organic carbon (TOC) measurements (monthly sampling) were performed both during a few flood events and during recession periods (Figure 3). Generally, measured TOC values were low, ranging within $0.1-0.6 \mathrm{mg} / \mathrm{L}$. Low values were consistent with the findings of other studies, characterizing TOC as a short lived tracer in karst systems which marks only very fast transport of water from soil to the spring [32,34,54-57]. Samples taken during or shortly after the high recharge events on both springs showed increased TOC content, while it was relatively constant during recession periods (Figure 3). TOC content of the periodic spring water was consistently slightly increased compared to the main spring, although its TOC content was also quite low. This indicates somewhat greater presence of very young water discharging at the periodic spring. Highest TOC contents on both springs were present during the first significant flood event in the beginning of the wet season (November and December 2017), probably due to the higher production rates in soil during preceding vegetation period. However, more detailed analysis of TOC dynamics requires the higher sampling resolution, especially during high recharge events.

\subsection{Dissolved Oxygene (DO) Dynamics}

Dissolved oxygen (DO) content monitored on the main spring revealed its clear dependence on the flow dynamics. Similar to SEC, highest DO concentrations in the spring water were observed during high water conditions, several days after the hydrograph peaks, while during dry periods concentrations were lower. This was consistent with visual observations of bubbling intensity in a spring pool, which indicated presence of "excess air" in water. During hydrograph peaks oxygen concentration temporarily drops with a delay of the minimum concentration to hydrograph peak of approximately 1 day (Figure 7, phase 1 on Figure 8). Start of DO decrease was synchronous with SEC, but double-lows of SEC preceded DO minimum by approximately 10 and $20 \mathrm{~h}$, respectively. Afterwards, DO rises were more gradual comparing to SEC, reaching maximum values 12 days after the hydrograph peak. Hysteresis curve of DO vs. discharge reflected slower recovery of DO in comparison to SEC (phase 2 on Figure 8).

Increased DO concentration was indicator of air supersaturation, i.e., excess air in spring water, known to be occasionally present in the main spring water, making Krbavica stream inadequate for fish farming purposes. Although oxygen cannot be considered as a non-reactive tracer due to possible oxidation processes within the aquifer, monitoring of DO dynamics showed that it is controlled mainly by flow dynamics. This suggests that oxidation processes in a karst system like the Krbavica catchment probably do not influence DO concentration significantly, especially during high flow conditions.

The transition from partial to complete water saturation, i.e., transition from open to closed flow conditions in medium and small fractures within vadose zone during high recharge conditions can cause supersaturation of spring water with air, and consequently increased oxygen saturation. Air bubbles captured in the fractures and transported with the downward water flow are subjected to a gradual pressure rising. The bubbles gradually dissolve in water due to a raised pressure and remain dissolved as long as flow is in closed conditions. On contrary, water flow through large, karstified fractures and conduits within vadose zone is always in open flow conditions, i.e., dissolved gasses pressure is equilibrated with the surrounding atmosphere pressure. Consequently, drops in oxygen saturation during hydrograph peaks can be attributed to increased portion of flow through large voids within vadose zone. During recession after the hydrograph peak, flow through completely saturated fractures gradually becomes dominant, which is marked by increase in air saturation of the spring water. Additionally, in order for groundwater to remain supersaturated, conduits within the deeper parts of the system that drain water to the spring should also be in closed flow conditions, i.e., dominantly phreatic (situated below the groundwater level) and isolated from the atmosphere. Transition back to open flow conditions in some of the vadose zone fractures during decreasing recharge was marked by decrease of oxygen saturation during later phases of the hydrograph recession. It can be concluded that the air saturation dynamics implied both information on the characteristics of the flow within vadose 
zone as well as information on the characteristics of the main conduit networks within the deeper zone of the system. Therefore, DO monitoring on the Krbavica spring revealed domination of flow through medium to narrow fractures in vadose zone shortly after the flood peaks and continuation of close flow conditions in the deeper parts of the system up to the spring.

\subsection{Stable Isotopes}

All spring water samples were aligned along the local meteoric water line (LMWL), defined by the monthly precipitation samples. This confirmed meteoric origin of the water from the springs as well as insignificant evaporation of the precipitations before infiltration to the subsurface (Figure $9 \mathrm{~b}$ ). Due to high linear correlation of $\delta^{18} \mathrm{O}$ and $\delta^{2} \mathrm{H}$ values (correlation coefficient of 0.98 ), only $\delta^{18} \mathrm{O}$ are further considered.
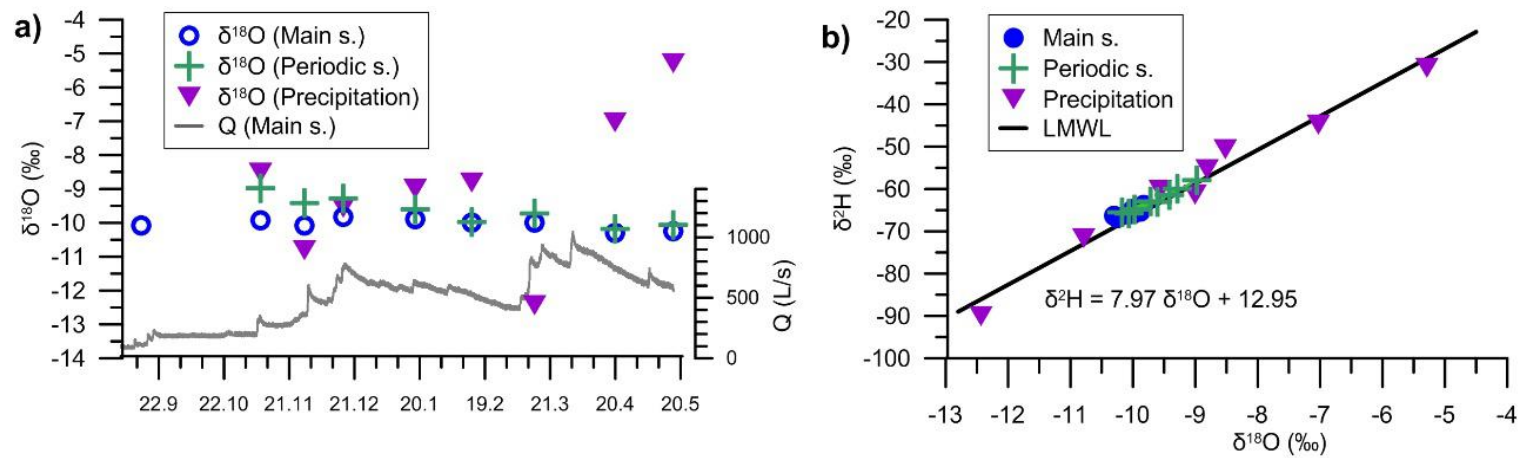

Figure 9. Stable isotope composition of the springs water and local precipitation: (a) Changes of $\delta^{18} \mathrm{O}$ in time and hydrograph of the main spring $(\mathrm{Q}) ;(\mathbf{b})$ Composition of $\delta^{2} \mathrm{H}$ and $\delta^{18} \mathrm{O}$ in all samples, and the local meteoric water line (LMWL) resulting from the bulk precipitation compositions.

Weighted mean $\delta^{18} \mathrm{O}$ of precipitation was $-8.79 \%$, while mean of the main and periodic spring waters were $-10.04 \%$ o and $-9.65 \%$ o respectively. Both springs showed lower mean values compared to the weighted mean of precipitation, although summer precipitation values, which should have more positive values, were not measured. This was partly a result of elevation gradient of precipitation isotopes, as the precipitation samples were collected on the springs elevation, while mean elevation of the catchment is approx. $250 \mathrm{~m}$ higher. Reported values of $\delta^{18} \mathrm{O}$ altitude gradient measured in Dinaric part of Croatia range from $-0.2 \%$ o to $-0.3 \%$ o $/ 100 \mathrm{~m}$ [58,59]. If gradient of $-0.25 \% \mathrm{o} / 100 \mathrm{~m}$ is accepted for the Krbavica catchment, mean precipitation value for the catchment should be lowered to $-9.42 \%$. Although this value is closer to the observed spring water values, it is still higher, especially in comparison to the main spring value. Additional cause for the lower spring water values can be attributed to significantly higher recharge during colder part of the year due to lower evapotranspiration, marked also by pronounced seasonality in the hydrographs (much stronger seasonality than in precipitations).

Water samples of both springs showed highly attenuated variations in the isotope values compared to the precipitation samples (Figure 9a). Total range observed in the precipitation samples amounted $7.15 \%$, while in the main and periodic spring water samples amounted $0.48 \%$ ond $1.20 \%$ o respectively. Considering short period of monitoring, the observed range in precipitation was compared to the yearly amplitudes observed on the other monitoring stations located in the vicinity (within a few tens of $\mathrm{km}$ ) where longer monitoring periods were available. Mean yearly amplitudes observed at the nearby Plitvce lakes, Gospić town [60], Gacka river [61], and North Velebit Mt. [62] were all in the range of 7-9\%o, what is very close to the range observed in this study. Therefore, the observed range can serve as an indicator of mean yearly amplitude in isotopic values of precipitation on Krbavica catchment, despite monitoring period shorter than one year. Regarding seasonal variations in karst spring water, presence of freshly infiltrated water during storm events can significantly influence its isotopic composition. Therefore, samples collected during the peaks on hydrograph (and lows 
on chemograph) should be discarded if seasonal variations are considered. When we applied this on the Krbavica springs water samples (samples taken in November and December 2017 and March 2018 were discarded), the observed ranges were even smaller: $0.42 \%$ on the main and $0.76 \%$ on the periodic spring. It should be mentioned that annual amplitudes below $0.5 \%$ o were reported also for the nearby karst springs of the Gacka River, based on multiyear monitoring period [61,63].

Estimation of spring water mean residence time (MRT) in baseflow conditions based on Equation (2) and observed amplitudes in isotopic values, yielded values of 2.7 years for the main, and 1.5 years for the periodic spring. As amplitudes were determined for a short monitoring period, and the amplitude for the main spring was hardly observable, obtained values of MRTs should be regarded as approximate, but indicative and useful for comparison with data reported in other studies of karst springs and aquifers.

If only samples collected during the hydrograph recessions are analyzed, on both Krbavica springs, slight decrease in the heavy isotope contents was present during winter season, until samples collected in May showed slight increase. A decrease in the spring water samples was delayed by a few months in regard to the precipitation samples. All three samples taken during the hydrograph peaks had slightly elevated values, more elevated on the periodic spring. This indicated presence of less heavy isotope depleted water of intensive precipitation that partly bypassed storages of the system and flowed rapidly through conduits to the springs.

\section{Discussion and Concluding Remarks}

The elaborated results showed that although every monitored parameter included in this study provided valuable information of the system, each one interpreted separately could rarely provide firm and unambiguous conclusions. However, common analysis and interpretation of diverse parameters, i.e., environmental tracers enabled relatively detailed characterization of flow properties in this karst system.

Non-reactive tracers, such as stable isotopes content of hydrogen and oxygen, provided the most reliable information on degree of water mixing within the system, buffering of the input signal as well as potential and dynamics of rapid water transfer from karst surface to the springs. On the other hand, very fast dynamics of the karst springs required very high data frequency of the monitored parameters (preferably hourly or at least daily) in order to reveal characteristics of the dynamics in detail. This is very difficult to achieve by water sampling, especially during longer periods. Therefore, parameters measured by automated logging devices (level/discharge, SEC, temperature, DO concentration) provided the most detailed insight in the system dynamics. Parameters measured with high frequency also served for determination of the system state at the time of sampling (hydrograph peaks/chemograph lows vs. recession/recovery periods). Consequently, low frequency data could be interpreted much more reliably due to availability of other, simultaneously measured high frequency data series.

The analysis of the major ion content in the spring water served to confirm exclusively carbonate, prevailingly limestone, rock composition within the catchment subsurface. $\mathrm{Mg} / \mathrm{Ca}$ ratio provided information both on dolomite/limestone shares in the hinterlands of the individual spring, as well as on relative residence time of spring water in various hydrological conditions. Interpretation of SEC dynamics alone is generally ambiguous due to the existence of two main controlling factors that could influence its dynamics: duration of water-rock interaction and dynamics of water $\mathrm{CO}_{2}$ concentration. However, simultaneous increase in both $\mathrm{Mg} / \mathrm{Ca}$ ratio and SEC is a strong indicator of increased groundwater residence time. Absence of observable seasonal pattern in SEC dynamics on the monitored springs, which could be attributed to seasonal changes in soil $\mathrm{CO}_{2}$ concentrations [49], pointed to good mixing of water within the system on at least annual, or longer scale. Strong attenuation of seasonal changes of stable isotope contents further confirmed effective mixing of groundwater within the system with estimated mean residence times longer than one year. Instead of seasonal 
pattern, discharge dynamics was the principal controlling factor for SEC dynamics, i.e., spring water mineralization, during the monitoring period.

The Krbavica springs water mean residence time, i.e., "old" groundwater share, marked by both SEC dynamics and $\mathrm{Mg} / \mathrm{Ca}$ ratio, seemed to be higher in high water conditions at the beginnings of recession periods than in later stages of hydrograph recession in low water conditions. This was contrary to general interpretation that mean residence time of karst groundwater is increasing during recession periods due to gradual draining of less and less permeable fractures. Author [17] called SEC decrease during a hydrograph recession anomalous, and explained it by variable flow directions, i.e., variable extent of the catchment area. However, we consider that in the case of the Krbavica springs more plausible explanation for similar dynamics was mobilization of water bound by adhesive forces within tiny fractures by increased pressure during high recharge conditions, together with water oversaturation with $\mathrm{CO}_{2}$ rich air from soil/epikarst and vadose zone. The water contained in tiny fractures presents the slowest moving component of the water within the system, marked by longest residence time and consequently in chemical equilibrium with respect to surrounding rocks.

Monitoring of DO concentration was used to confirm spring water supersaturation with air, a phenomenon formerly indicated by bubble formation in the spring pool as well as inadequacy of its water for fish farming. Maximum DO concentrations appeared in high water conditions, several days after the hydrograph peaks, similar but slightly delayed comparing to SEC maximums. Generally, water flow in a vadose zone of a karst system can be separated into three types: (1) always saturated flow through tiny fissures; (2) flow through intermediate fissures which is saturated in high recharge conditions and partly saturated during lower recharge; and (3) flow through conduits/large fractures which is never fully saturated [54,64]. During high recharge conditions air trapped in medium-to-narrow fractures is gradually dissolved in water due to increasing pressure and closed flow conditions.

Supersaturation with air from soil, epikarst, and/or vadose zone can significantly increase $\mathrm{CO}_{2}$ concentration in water, and consequently its aggressiveness to carbonate rocks. Therefore, supersaturation with $\mathrm{CO}_{2}$ rich air can also cause increased water mineralization, reflected by SEC. Generally, similar dynamics of SEC and DO concentrations, both positively correlated to discharge during hydrograph recessions, indicated influence of the proposed mechanism on water mineralization. However, different reaction times to hydrograph increases, as well as much longer DO recovery to maximum values after the hydrograph peaks indicated that air supersaturation was not the only controlling factor, but SEC was influenced also by increased contribution of water from low permeable fractures. Anyhow, particular significance of these two mechanisms should be further examined.

Additional cause for retardation of DO dynamics could be related to variations in consumption of oxygen due to oxidation processes in the system. Increase in oxidation rates can be induced by increased transport of organic matter from the surface/soil during high recharge conditions. Nevertheless, significance of this mechanism should be confirmed by additional monitoring of nitrogen, or total dissolved gasses saturation in future studies.

The spring water supersaturation with air indicated domination of closed flow conditions within the system, from the infiltration to the soil and epikarst, through vadose and phreatic zones to the spring locations. This also implies phreatic nature of the main conduit system and ascending character of flow at the spring. Increased SEC in high flow conditions also confirms an absence of conduit ventilation that can lower $\mathrm{CO}_{2}$ concentrations in water, and consequently its mineralization [41,49]. Dominance of closed flow conditions within the system is characterizing its relatively early stage of development, reflected in presumable absence of a large epiphreatic conduit system, connected with the surface and ventilated.

Attenuated discharge peaks of the main spring in comparison to the periodic spring additionally pointed to its limited outflow capacity, which causes activation of the periodic spring in high water conditions. During high water conditions, water of the springs was not fully mixed, while in low water conditions complete catchment was drained on the main spring. Higher TOC content on the periodic 
spring reflected relatively greater share of "young" water, while increased $\mathrm{Mg} / \mathrm{Ca}$ ratio was attributed to lithological composition of its hinterland, and not to increased groundwater residence time. Slow and delayed dynamics of water temperature pointed to its highly reactive nature. Temperature dynamics was mainly related to cooling and warming of rocks surrounding the main conduits, while not directly to water origin at the spring (contrary to SEC).

Presented results and discussion tried to emphasize how a number of different but interrelated processes happening within the karst hydrogeological systems can influence dynamics of various environmental tracers. Therefore, great caution should be paid when interpreting the monitoring results in order to avoid oversimplifications or wrong attributions of observed patterns. Inclusion of multiple and diverse tracers in the monitoring can greatly reduce ambiguity of interpretation, although complete certainty is still hardly achieved. Dissolved gas saturation and/or air saturation in spring water was very rarely monitored in karst hydrogeological studies [15]. In this study, we presented usefulness of DO concentration monitoring, using air saturation as one of the indicators in analyzing water flow properties within the studied karst system.

Author Contributions: Conceptualization, A.S., M.B., and M.O.; methodology, A.S., M.B., and M.O.; formal analysis, M.B.; investigation, A.S. and M.B.; resources, Croatian Geological survey; data curation, A.S. and M.B.; writing-original draft preparation, A.S. and M.B.; writing-review and editing, A.S., M.B., and M.O.; visualization, A.S. and M.B.; supervision, A.S.; project administration, A.S.; funding acquisition, M.B. and A.S. All authors have read and agreed to the published version of the manuscript.

Funding: This research was funded by Hrvatske vode.

Acknowledgments: Authors would like to thank the anonymous reviewers for their careful review, which helped to improve the quality of the manuscript. The Croatian Geological Survey, Department of Hydrogeology and Engineering Geology supported this research (administrative and technical support and utilization of laboratory services). This paper is partly the result of training and education conducted through GeoTwinn project that has received funding from the European Union's Horizon 2020 research and innovation program under grant agreement No 809943 .

Conflicts of Interest: The authors declare no conflict of interest. The funders had no role in the collection, analyses, or interpretation of the data. The member of the funder's institution participated in the design of the study, the writing of the manuscript and in the decision to publish the results.

\section{References}

1. Ford, D.; Williams, P.D. Karst Hydrogeology and Geomorphology; John Wiley \& Sons: Chichester, UK, 2007. [CrossRef]

2. Goldscheider, N.; Drew, D. Methods in Karst Hydrogeology: IAH: International Contributions to Hydrogeology, 26; Taylor \& Francis: London, UK, 2007.

3. Stroj, A.; Paar, D. Water and air dynamics within a deep vadose zone of a karst massif: Observations from the Lukina jama-Trojama cave system $(-1,431 \mathrm{~m})$ in Dinaric karst (Croatia). Hydrol. Process. 2019, 33, 551-561. [CrossRef]

4. Worthington, S.R. A comprehensive strategy for understanding flow in carbonate aquifers. In Karst Modeling, Karst Waters Institute Special Publication 5, Proceedings of the Symposium, Charlottesville, VA, USA, 24-27 February 1999; Palmer, A.N., Palmer, M.V., Sasowsky, I.D., Eds.; Karst Waters Institute: Charles Town, VA, USA, 1999; pp. 30-37, ISBN 978-0-9640258-4-4.

5. Bakalowicz, M. The epikarst, the skin of karst. In Proceedings of the Interdisciplinary Workshop on Epikarst, Shepherdstown, VA, USA, 1-4 October 2003; Jones, W.K., Culver, D.C., Herman, J.S., Eds.; Karst Waters Institute: Charles Town, VA, USA, 2004; pp. 16-22.

6. Williams, P.W. The role of the epikarst in karst and cave hydrogeology: A review. Int. J. Speleol. 2008, 37, 1-10. [CrossRef]

7. Jones, W.K. Physical structure of the epikarst. Acta Carsologica 2013, 42, 311-314. [CrossRef]

8. Trček, B.; Zojer, H. Recharge of springs. In Groundwater Hydrology of Springs; Kresic, N., Stevanovic, Z., Eds.; Butterworth-Heinemann: Burlington, VT, USA, 2010; pp. 87-127. [CrossRef]

9. Heaton, T.H.E.; Vogel, J.C. “Excess air” in groundwater. J. Hydrol. 1981, 50, 201-216. [CrossRef] 
10. Machova, J.; Faina, R.; Randak, T.; Valentova, O.; Steinbach, C.; Kocour Kroupova, H.; Svobodova, Z. Fish death caused by gas bubble disease: A case report. Vet. Med. 2017, 62, 231-237. [CrossRef]

11. Weitkamp, D.E.; Katz, M. A Review of Dissolved Gas Supersaturation Literature. Trans. Am. Fish. Soc. 1980, 109, 659-702. [CrossRef]

12. Wilson, G.B.; McNeill, G.W. Noble gas recharge temperatures and the excess air component. Appl. Geochem. 1997, 12, 747-762. [CrossRef]

13. Aeschbach-Hertig, W.; Peeters, F.; Beyerle, U.; Kipfer, R. Palaeotemperature reconstruction from noble gases in ground water taking into account equilibration with entrapped air. Nature 2000, 405, 1040-1044. [CrossRef]

14. Chambers, L.A.; Gooddy, D.C.; Binley, A.M. Use and application of CFC-11, CFC-12, CFC-113 and SF6 as environmental tracers of groundwater residence time: A review. Geosci. Front. 2019, 10, 1643-1652. [CrossRef]

15. Surbeck, H. Dissolved Gases as Natural Tracers in Karst Hydrogeology; Radon and Beyond; Center of Hydrogeology (CHYN), University of Neuchâtel: Neuchâtel, Switzerlands, 2007.

16. Bonacci, O. Water circulation in karst and determination of catchment areas: Example of the River Zrmanja. Hydrol. Sci. J. 1999, 44, 373-386. [CrossRef]

17. Ravbar, N.; Engelhardt, I.; Goldscheider, N. Anomalous behaviour of specific electrical conductivity at a karst spring induced by variable catchment boundaries: The case of the Podstenjšek spring, Slovenia. Hydrol. Process. 2011, 25, 2130-2140. [CrossRef]

18. Lukač Reberski, J.; Marković, T.; Nakić, Z. Definition of the river Gacka springs subcatchment areas on the basis of hydrogeological parameters. Geol. Croat. 2013, 66, 39-53. [CrossRef]

19. Bonacci, O.; Terzić, J.; Roje Bonacci, T.; Frangen, T. An Intermittent Karst River: The Case of the Čikola River (Dinaric Karst, Croatia). Water 2019, 11, 2415. [CrossRef]

20. Zaninović, K.; GajičČapka, M.; Perčec Tadić, M.; Vučetić, M. Klimatski Atlas Hrvatske Climate Atlas of Croatia 1961-1990. 1971-2000; Državni hidrometeorološki zavod: Zagreb, Croatia, 2008; ISBN 978-953-7526-01-6.

21. Kresic, N.; Bonacci, O. Spring discharge hydrograph. In Groundwater Hydrology of Springs; Kresic, N., Stevanovic, Z., Eds.; Butterworth-Heinemann: Burlington, VT, USA, 2010; pp. 129-163. [CrossRef]

22. White, W.B. Springwater geochemistry. In Groundwater Hydrology of Springs; Kresic, N., Stevanovic, Z., Eds.; Butterworth-Heinemann: Burlington, VT, USA, 2010; pp. 231-268. [CrossRef]

23. Terzić, J.; Stroj, A.; Frangen, T. Hydrogeological investigation of karst system properties by common use of diverse methods: A case study of Lička Jesenica springs in Dinaric karst of Croatia. Hydrol. Process. 2012, 26, 3302-3311. [CrossRef]

24. Mangin, A. Pour une meilleure connaissance des systèmes hydrologiques à partir des analyses corrélatoire et spectrale. J. Hydrol. 1984, 67, 25-43. [CrossRef]

25. Padilia, A.; Pulido Bosch, A. Study of hydrographs of karst aquifers by means of correlation and cross-spectral analysis. J. Hydrol. 1995, 168, 73-89. [CrossRef]

26. Tamburini, A.; Menichetti, M. Groundwater Circulation in Fractured and Karstic Aquifers of the Umbria-Marche Apennine. Water 2020, 12, 1039. [CrossRef]

27. Kuhta, M.; Brkić, Ž.; Stroj, A. Hydrodynamic characteristics of Mt. Biokovo foothill springs in Croatia. Geol. Croat. 2012, 65, 41-52. [CrossRef]

28. Piper, A.M. A graphic procedure in the geochemical interpretation of water-analyses. EosTrans. Am. Geophys. Union 1944, 25, 914-928. [CrossRef]

29. White, W.B. Geomorphology and Hydrology of Karst Terrains; Oxford Univ. Press: New York, USA, 1988; ISBN 0195044444.

30. Appelo, C.A.J.; Postma, D. Geochemistry, Groundwater and Pollution, 2nd ed.; Balkema: Rotterdam, The Netherlands, 2005; ISBN 9780415364287.

31. Lastennet, R.; Mudry, J. Role of karstification and rainfall in the behavior of a heterogeneous karst system. Environ. Geol. 1997, 32, 114-123. [CrossRef]

32. Emblanch, C.; Blavoux, B.; Puig, J.M.; Mudry, J. Dissolved organic carbon of infiltration within the autogenic karst hydrosystem. Geophys. Res. Lett. 1998, 25, 1459-1462. [CrossRef]

33. Batiot, C.; Emblanch, C.; Blavoux, B. Total Organic Carbon (TOC) and magnesium $\left(\mathrm{Mg}^{2+}\right)$ : Two complementary tracers of residence time in karstic systems. CR Geosci. 2003, 335, 205-214. [CrossRef] 
34. Mudarra, M.; Andreo, B. Hydrogeological functioning of a karst aquifer deduced from hydrochemical components and natural organic tracers present in spring waters. The case of Yedra Spring (Southern Spain). Acta Carsologica 2010, 39, 261-270. [CrossRef]

35. Clark, I.; Fritz, P. Environmental Isotopes in Hydrogeology; CRC Press: Boca Raton, FL, USA, 1997. [CrossRef]

36. Małoszewski, P.; Rauert, W.; Stichler, W.; Herrmann, A. Application of flow models in an alpine catchment area using tritium and deuterium data. J. Hydrol. 1983, 66, 319-330. [CrossRef]

37. McGuire, K.J.; McDonnell, J.J. A review and evaluation of catchment transit time modeling. J. Hydrol. 2006, 330, 543-563. [CrossRef]

38. Williams, P.W. The role of the subcutaneous zone in karst hydrology. J. Hydrol. 1983, 61, 45-67. [CrossRef]

39. Hess, J.W.; White, W.B. Storm response of the karstic carbonate aquifer of southcentral Kentucky. J. Hydrol. 1988, 99, 235-252. [CrossRef]

40. Frank, S.; Goeppert, N.; Goldscheider, N. Fluorescence-based multi-parameter approach to characterize dynamics of organic carbon, faecal bacteria and particles at alpine karst springs. Sci. Total Environ. 2018, 615, 1446-1459. [CrossRef]

41. Covington, M.D.; Vaughn, K.A. Carbon dioxide and dissolution rate dynamics within a karst underflow-overflow system, Savoy Experimental Watershed, Arkansas, USA. Chem. Geol. 2019, 527, 118689. [CrossRef]

42. Hunkeler, D.; Mudry, J. Hydrochemical methods. In Methods in Karst Hydrogeology: IAH: International Contributions to Hydrogeology, 26; Goldscheider, N., Drew, D., Eds.; Taylor \& Francis: London, UK, 2007; pp. 93-121.

43. White, W. Chemistry and karst. Acta Carsologica 2015, 44, 349-362. [CrossRef]

44. Dreybrodt, W. Limestone dissolution rates in karst environments. Bull. D'hydrogéologie 1998, 16, 167-183.

45. Lakey, B.; Krothe, N.C. Stable isotopic variation of storm discharge from a perennial karst spring, Indiana. Water Resour. Res. 1996, 32, 721-731. [CrossRef]

46. Sauter, M. Differentiation of flow components in a karst aquifer using the $\delta^{18} \mathrm{O}$ signature. In Tracer Hydrology 97; Kranjc, A., Ed.; Balkema: Rotterdam, The Netherlands, 1997; pp. 435-441, ISBN 109054108754.

47. Perrin, J.; Jeannin, P.Y.; Zwahlen, F. Epikarst storage in a karst aquifer: A conceptual model based on isotopic data, Milandre test site, Switzerland. J. Hydrol. 2003, 279, 106-124. [CrossRef]

48. Shuster, E.T.; White, W.B. Source areas and climatic effects in carbonate groundwaters determined by saturation indices and carbon dioxide pressures. Water Resour. Res. 1972, 8, 1067-1073. [CrossRef]

49. Jeannin, P.Y.; Malard, A.; Häuselmann, P.; Meury, P.X. Effect of cave ventilation on karst water chemographs. In EuroKarst 2016, Neuchâtel, Advances in the Hydrogeology of Karst and Carbonate Reservoirs; Renard, P., Bertrand, C., Eds.; Springer: Cham, Switzerland, 2017; pp. 129-139. [CrossRef]

50. Atkinson, T.C. Carbon dioxide in the atmosphere of the unsaturated zone: An important control of groundwater hardness in limestones. J. Hydrol. 1977, 35, 111-123. [CrossRef]

51. Benavente, J.; Vadillo, I.; Carrasco, F.; Soler, A.; Liñán, C.; Moral, F. Air Carbon Dioxide Contents in the Vadose Zone of a Mediterranean Karst. Vadose Zone J. 2010, 9, 126-136. [CrossRef]

52. Covington, M.D.; Luhmann, A.J.; Wicks, C.M.; Saar, M.O. Process length scales and longitudinal damping in karst conduits. J. Geophys. Res. Earth Surf. 2012, 117, F01025. [CrossRef]

53. Birk, S.; Liedl, R.; Sauter, M. Karst spring responses examined by process-based modeling. Groundwater 2006, 44, 832-836. [CrossRef]

54. Pronk, M.; Goldscheider, N.; Zopfi, J.; Zwahlen, F. Percolation and particle transport in the unsaturated zone of a karst aquifer. Groundwater 2009, 47, 361-369. [CrossRef]

55. Mudarra, M.; Andreo, B. Relative importance of the saturated and the unsaturated zones in the hydrogeological functioning of karst aquifers: The case of Alta Cadena (Southern Spain). J. Hydrol. 2011, 397, 263-280. [CrossRef]

56. Mudarra, M.; Andreo, B.; Marín, A.I.; Vadillo, I.; Barberá, J.A. Combined use of natural and artificial tracers to determine the hydrogeological functioning of a karst aquifer: The Villanueva del Rosario system (Andalusia, southern Spain). Hydrogeol. J. 2014, 22, 1027-1039. [CrossRef]

57. Charlier, J.B.; Bertrand, C.; Mudry, J. Conceptual hydrogeological model of flow and transport of dissolved organic carbon in a small Jura karst system. J. Hydrol. 2012, 460, 52-64. [CrossRef] 
58. Roller Lutz, Z.; Mance, D.; Hunjak, T.; Lutz, H.O. On the isotopic altitude effect of precipitation in the Northern Adriatic (Croatia). In Isotopes in Hydrology, Marine Ecosystems and Climate Change Studies, Proceedings of an International Symposium, Monaco, 27 March-1 April 2011; IAEA: Vienna, Austria, 2013; Volume 1, pp. 99-105, ISBN 978-92-0-135610-9.

59. Hunjak, T.; Lutz, H.O.; Roller Lutz, Z. Stable isotope composition of the meteoric precipitation in Croatia. Isot. Environ. Health Stud. 2013, 49, 336-345. [CrossRef] [PubMed]

60. IAEA WISER. Global Network of Isotopes in Precipitation, The GNIP Database. Available online: https: //nucleus.iaea.org/wiser/index.aspx (accessed on 2 July 2020).

61. Mandić, M.; Bojić, D.; Roller Lutz, Z.; Lutz, H.; Bronić Krajcar, I. Note on the spring region of Gacka River (Croatia). Isot. Environ. Health Stud. 2008, 44, 201-208. [CrossRef] [PubMed]

62. Paar, D.; Mance, D.; Stroj, A.; Pavić, M. Northern Velebit (Croatia) karst hydrological system: Results of a preliminary $2 \mathrm{H}$ and $18 \mathrm{O}$ stable isotope study. Geol. Croat. 2019, 72, 205-213. [CrossRef]

63. Ozyurt, N.N.; Lutz, H.O.; Hunjak, T.; Mance, D.; Roller Lutz, Z. Characterization of the Gacka River basin karst aquifer (Croatia): Hydrochemistry, stable isotopes and tritium-based mean residence times. Sci. Total Environ. 2014, 487, 245-254. [CrossRef]

64. Kogovšek, J. Water tracing tests in vadose zone. In Tracer Hydrology 97; Kranjc, A., Ed.; Balkema: Rotterdam, The Netherlands, 1997; pp. 167-172, ISBN 109054108754.

(C) 2020 by the authors. Licensee MDPI, Basel, Switzerland. This article is an open access article distributed under the terms and conditions of the Creative Commons Attribution (CC BY) license (http://creativecommons.org/licenses/by/4.0/). 